\title{
DiGITALISATION OF INDUSTRIES - A COMPARATIVE ANALYSIS FROM AUSTRALIA AND FINLAND
}

\author{
Pekka Leviäkangas $^{\text {a, b }}$ \& Osmo Kauppila ${ }^{b}$
}

a VTT Technical Research Centre of Finland Ltd., Smart Industry and Energy Systems, pekka.leviakangas@vtt.fi, PO Box 1100, 90571 Oulu, Finland.

${ }^{\mathrm{b}}$ University of Oulu, Industrial Engineering and Management, osmo.kauppila@oulu.fi, PO Box 8000, 90014 University of Oulu, Finland

Dr. Pekka Leviäkangas holds a PhD in technology. He has worked in management and expert positions in administration, business and academia. He is currently Principal Scientist at Technical Research Centre of Finland Ltd. and Adjunct Professor in industrial engineering and management at the University of Oulu.

Dr. Osmo Kauppila holds a PhD in technology. He is a lecturer in Industrial Engineering and Management at the University of Oulu. He is specialised in statistical methods, digitalisation, quality systems and project management.

\begin{abstract}
This paper features a two-country study on digitalisation: Australia and Finland. The empirical data was acquired from the national accounts for 1995-2015 in Australia and for 1998-2012 in Finland. This data was averaged for a cross-sectional comparison of industries and then for the two countries. Different industries' advancement in digitalisation seems to follow approximately the same pacing in both countries. Financial and insurance services, telecommunications and media, and professional, technical and scientific services are the most active digitalisers. The empirical testing of the $a$ priori assumption that digitalisation over a long period of time leads to greater productivity shows that the observed correlation between ICT investment and productivity is weak. The results partly confirm Solow's productivity paradox.
\end{abstract}

Keywords: digitalisation, industry, Finland, Australia, labour productivity, total productivity, ICT, investment, national accounts, rank correlation.

\section{INTRODUCTION}

The information and communication technology (ICT) revolution has taken place everywhere. We may call this revolution by different terms, such as digitalisation or digitisation. These two term variants are often used interchangeably, although market-research firm Gartner (Prause, 2016) gives the former-mentioned variant a more holistic meaning so that digitalisation includes new processes and value propositions whereas digitisation is about transforming the analogue world into a digital format. Basically, we are transforming our perception of the world from analogue and human-sensed into a digitally sensed perception, which in turn is processed and translated into languages or formats that humans can understand and act upon. Digitalisation is by far the most significant technological trend globally, and its impacts will be enhanced as other technologies, such as automation and robotics are integrated with it. This fundamental change in technology will affect individuals, communities, corporations and entire nations.

The World Economic Forum (WEF) forecasts that almost one trillion sensors will be connected to the internet by the year 2025 (World Economic Forum, 2015a). The impacts could be radical, and not just the technologically speaking. The Organisation of Economic Co-operation and Development (OECD) foresee that a new risk is emerging when digitalisation progresses further. A new type of unemployment may be 
faced by many societies if digital literacy and ICT skills are not specifically addressed by education systems (OECD, 2014). There is a prospect of a mismatch between 'digital workers' who possess ICT skills and those who merely use them or are entirely outside of the digital economy. The European statistics office Eurostat shows that routine jobs have declined constantly since 2005. Indeed, there has been a drop of more than $10 \%$ in less than a decade - meaning roughly one per cent unit per annum (European Commission, 2015a).

Different countries, industries and sectors make progress in digitalisation at a varied pace. For instance, Finland was ranked the seventh by the WEF for 2015-2016 in overall competitiveness, 13th in technological readiness but 1 st in the availability of latest technologies. Technology absorption by Finnish firms was ranked 10th (World Economic Forum, 2015b). The European Digital Agenda Scoreboard placed the Nordic countries Denmark, Sweden and Finland in the top three regarding the aspects of connectivity, human capital, use of internet, integration of digital technologies and digital public services (European Commission, 2015b).

On the other side of the globe, too, digitalisation is progressing just as relentlessly. Right before the parliamentary elections that took place in 2016, the Australian government launched the 'National Innovation and Science Agenda', which listed prioritised investment in digitalisation. The digital agenda is clearly seen in the 'government as an exemplar' section. This section identifies action points, such as public data utilisation, digital marketplaces for government ICT procurement and pre-commercial procurement (Commonwealth of Australia, 2015). Formulated industry agendas for the digitalisation of Australian industries are not that common, but there is no doubt that industrial leaders are well aware of the challenge the digital and associated technological disruption will bring (Brea et al., 2013). Australia is ranked 21st in overall technological readiness and 22nd in firm-level technology absorption (European Commission, 2015b). The aim of the Australian government is to reshape Australia into a leading digital economy and enhance the country's industrial productivity, maintain its global competitiveness and improve social wellbeing.

Digitalisation is generally presumed to increase industrial productivity, but unfortunately the evidence is not entirely solid. As Straus and Samkharadze (2011) point out, the impacts of ICT on total productivity have not been convincing in Europe in particular. The correlation between digitalisation and productivity is perceived as a result of a deliberate strategy to invest in technology and increasingly in automation and ICT. This, in turn, will reduce the dependency on human labour, which is subject to health and safety risks, not to mention variations in productivity between individuals. Production becomes more controllable, continuous and with little variation in quality of the output. However, unless efficient and streamlined processes, plus many other necessary measures, are introduced in pace with digitalisation, the desired outcomes might not be achieved. When the Australian construction industry and the Finnish transport sector (a compilation of different industry accounts) was analysed by Leviäkangas et al. (2017) and Leviäkangas (2016), the results of comparisons between industries and correlating long-range average productivity with ICT investment, showed that investment in ICT did not necessarily reflect productivity growth, at least to the extent one would expect. Andrews et al. (2016) investigated an international sample of forerunner global firms and found that a gap in productivity between the firms who 'get it' and the rest. Productivity development, particularly in the Euro Area, the UK, Australia, Canada and New Zealand has raised concerns (OECD, 2015). Cardona et al. (2013) made a literature review and found a correlation between ICT investment and productivity, although many of the reviewed studies were based on surveys (or were literature studies themselves) (Brynjolfsson and Hitt, 2000; Brynjolfsson and Yang, 1996; Holt and Jamison, 2009; Stiroh, 2005) and many studies reported measurement challenges.

There seems to be a different evolutionary path for different sectors and industries, or at least the pacing of digital technologies' diffusion is different. In the United States, construction has been the least digitalised sector, whereas the financial industry and business services have been the most advanced in adopting digital technologies (OECD, 2012). The general picture from the US and Europe is very similar: for example construction is one of the tail holding industries (Friedrich et al., 2011). Not only are industries making use of digital technologies, non-government organisations and civil society are digitalising their processes and operations, too (Shin and Chen, 2016). 


\section{SCOPE, AIMS AND THEORETICAL GROUNDING}

This paper analyses the long-range digitalisation of industries in two countries: Australia and Finland. The selection of cases is pragmatic and based on the fact that exceptionally good public records of national accounts can be found from those countries and that the accounts for digitalisation (investment in ICT) are identical. The paper seeks to show that there is a good deal of similarity between the two countries as to digitalisation pacing of industries. The countries are somewhat similar when considering their standard of living, income level and market characteristics: both have strong primary industries relying on natural resources (Australia with mining, oil, gas; Finland with the forestry industry). Differences are found regarding their governance structures, geography and climatology. The selection of industries is partly heuristic and partly a convenient sample. The countries were separately analysed previously by Leviäkangas et al. (2017) and Leviäkangas (2016) and the selected industries were present in these aforementioned studies. The aim here is to show that despite the differences, the progress of industrial digitalisation has a similar pattern. The contribution and added value of this research comes from the comparison of two countries' digitalisation, and especially from using a uniform methodological approach and comparable data sets in doing so. Such a comparison, the digitalisation of two countries' industries with and identical method and data, has not been previously reported in the academic literature to the authors' knowledge. The approach is descriptive and empirical and due to a focus on two countries, it is also a cross-country case study. This approach is suited for gaining a more detailed understanding of the digitalisation of industries and provides starting points for theory and hypotheses building. Case studies can be regarded as a form of empirical inquiry, but there are often descriptive and interpretative elements present (Yin, 2014). Using a cross-country approach, a single case study is strengthened with a comparative analysis (see examples of country comparisons, e.g. Wonglimpiyarat, 2018).

The paper is divided into the following sections. First, digitalisation as a mega-trend is introduced and briefly discussed; such discussions are well covered in the literature, e.g. Berger and Frey (2016), Brynjolfsson and MacAfee (2014). Second, the scope, aims, methods and data are explained; also the essential definitions are presented, relying mainly on Eurostat definitions. Third, country-specific statistics, both from Australia and Finland, are introduced, descriptively discussed and a rank correlation analysis performed to capture whether digitalisation associates with productivity development differences between the industries. Fourth, a comparison between the two countries' subset of industries is performed using simple and robust regression techniques; the following hypothesis is tested: there is a correlation when comparing the countries' industries in terms of progress and investment in digitalisation against the null hypotheses that there is no correlation. Fifth, the results are discussed and evaluated and finally, implications for further research and other countries are presented.

The theoretical foundations that can be associated with this paper are numerous. A classic example is Joseph Schumpeter's ideas on innovation and technological disruption (Sweezy, 1943; Ziemnowicz, 2013). Schumpeter had the notion of an 'innovative entrepreneur', that is, taking technological progress forward and enhancing business prospects by introducing new methods of manufacturing, new raw materials, new markets and new products, each of these having the attributes of 'an innovation'. ICT and digitalisation could represent many of the innovation concepts introduced by Schumpeter, a true pioneer with his ideas on economics, innovation, technology and entrepreneurship. At first, Schumpeter had the idea of an individual entrepreneur who, due to his/her curiosity, 'drive' and opportunity-seeking, would bring new ideas to industrial processes and products and improve them so that both the entrepreneur and the community as a whole would be better off. At the same time, the existing market equilibrium would be disrupted and the old processes that were of less utility would die out during the course of market competition (creative destruction). Later, Schumpeter underlined the importance of large corporations (this was when he moved to the United States before World War II) with their resources and professional management in innovating new products, services, markets and processes. Schumpeter had already published his first pioneering ideas in German in 1911, but 'The Theory of Economic Development: An Inquiry into Profits, Capital, Credit, 
Interest, and the Business Cycle' was published in English in 1934 (Schumpeter, 1934). The Schumpeterian ideology is clearly present in digital disruption.

Another theoretical underpinning is Solow's paradox, treated, for example, in Triplett (1999), Acemoglu et al. (2014), Shinozaki (2008), and Solow (1987). In particular, Acemoglu's et al. work is interesting as they seem to capture some of the same findings as the present paper: ICT and productivity do not necessarily go hand in hand when using industry-level data. Solow's widely quoted statements include the following: "You can see the computer age everywhere but in the productivity statistics" (Solow, 1987). This statement has been debated by researchers, one group of which claim that productivity measures do not capture quality improvements, for example.

ICT is supposed to improve and change the processes of industries, not so much affecting the final products. However, it must be recognised immediately that this perception may be outdated now, since in many situations, the digital value-adding layer has begun to be an integral part of the physical product. After-sales services automatically requested by the embedded intelligence in the product are just one example. But so far, it is evident that digitalisation has had more impact on supply chains, design, manufacturing, sales and managerial processes than on the final products of any manufacturing and delivery process. A car is still essentially a car and a house is still a house. It is equally evident that this might change in the not-so-distant future as the technology becomes integrated with the products as well as services. Digitalisation is increasingly playing a role in product-service systems (Baines et al., 2007) since ICT can be used to integrate the two components seamlessly. For example, with digitalisation, a car knows when it needs to be maintained and it can inform both the driver and the maintenance service provider about this need. Also, pure services are increasingly innovation-driven thanks to digitalisation and automation enabling novel service concepts (Drejer, 2004).

Digitalisation, as a form of technological change and implementation, can be regarded as a theoretical problem how technology interacts and affects organisations and people (see e.g. Leonardi and Barley, 2008), how technology is diffused in organisations (see e.g. Rogers, 1983; Jovanovic and MacDonald, 1994) and "a way of doing things in an organisation" (see e.g. Perrow, 1967 and his contingency theory), just to name a few. Much of the content of theoretical constructs deals with the utility and impacts of technology adoption. As to methodological choices, this paper assumes a straightforward empirical observation and testing and hence contributes first and foremost to the 'art'. As Colander (1992, p. 195) says, "In the art of economics a wide range of observation and empirical exploration is appropriate. Often simple statistics, tables, charts and case studies are appropriate..." By doing so, the message that this paper attempts to deliver will not be lost in the finesses of methodologies and analytical techniques.

The practical implications of this paper follow from the comparative analysis between Australia and Finland. If the hypothesis that industries follow a similar pace in digitalisation seems correct, it will signal to the managers of organisations - especially those dealing with ICT and technology - that certain industries need to be followed with a keen eye in order to see what is coming in terms of digital disruption. Benchmarking one's own industry can be a useful exercise in many ways. Another important practical perspective will be addressing the innovation and technology policy. If the initial assumption holds that industries follow technology diffusion (i.e. in this case, digitalisation) with an identical pattern, so that certain industries take the natural lead and the others will be following on their tail, and should this take place regardless of the country, the policy implications could be radical. Since different countries most likely have slightly differing technology and innovation policies and strategies, partly due to the economic and industrial structures, the effectiveness of these policies may come partly into question if the technology diffusion nevertheless follows some given patterns. For instance, some mature industries probably succeed better if no bold digital leaping is attempted before the new technologies are mature enough and have diffused in other industries first so that application consequences can be clearly seen. It is also noteworthy that digital technologies can be equally divided into emerging and more mature ones - if things can be made to work with $4 \mathrm{G}$ mobile technologies, why not do deploy that instead of waiting for $5 \mathrm{G}$ and reduce the risks involved in too ambitious leaps? 


\section{METHODS AND DATA}

The data is drawn mainly from the national accounts hosted by the Australian Bureau of Statistics and Statistics Finland. These accounts follow the standard national account classification system largely compatible within the OECD member states. The System of National Accounts sixth edition 5216.0 (Australian Bureau of Statistics, 2016) is used as the main source of the Australian data. The Finnish data follows the industry classification applied by Statistics Finland (www.statfin.fi), which in turn is compliant with Eurostat coding and definitions. Both accounting systems comply with the United Nations' System of National Accounts (United Nations, 2009). The highest level codes are shown in Table 1. Codes in italics are the industries that are covered for both countries and form the comparative analysis. From both countries, nine industries were included, as shown in Table 1.

Table 1. Industries included in the analysis (in italics the industries used in country comparison).

\begin{tabular}{|l|l|l|l|}
\hline Code & Industry & Code & Industry \\
\hline A & Agriculture, forestry and fishing & B & Mining \\
\hline C & Manufacturing & D & Electricity, gas, water and waste services \\
\hline E & Construction & F & Wholesale trade \\
\hline G & Retail trade & H & Accommodation and food services \\
\hline I & Transport, postal and warehousing & J & Information media and telecommunications \\
\hline K & Financial and insurance services & L & Rental, hiring and real estate services \\
\hline$M$ & Professional, scientific and technical services & N & Administrative and support services \\
\hline O & Public administration and safety & P & Education and training \\
\hline Q & Health care and social assistance & R & Arts and recreation services \\
\hline S & Other services & & \\
\hline
\end{tabular}

The data covers different time series. For Finland, the data for 1990-2012 was accessed via portals of Statistics Finland between December 2015 and February 2016 (https://tilastokeskus.fi/index_en.html). For Australia, the time series covers 1995-2015 and was accessed between October 2016 and February 2017 (http://www.abs.gov.au/). The variables studied were averaged for the comparative analysis of industries and from there to a comparison of the two case countries. The economic variables retrieved from the national accounts and applied in the analysis are shown in Table 2. We make the following definition for the word 'digitalisation' used in this paper: digitalisation refers to the long-term investment made in information and communication technologies. Our a priori assumption is that long-term averages of ICT investment should be reflected in long-term averages of productivity.

Digitalisation is approximated by the level of investment made in ICT. ICT includes the following accounts: computer software (computer programs, program descriptions and supporting materials for both systems and applications software), computers and peripherals (computer hardware and physical accessories) and electric and electronic equipment (ICT-related hardware, such as network transmitters and receivers, readers and ICT-connected appliances). ICT investment, rather than the ICT capital stock, works as a proxy for digitalisation since the time periods for both countries are long enough to allow the stock to be turned over multiple times during the analysis (ICT equipment has a lifespan of approximately 3-5 years on average; OECD, 2009). Therefore, the investment, in fact, builds a more reliable picture of the level of ICT intensity and willingness to advance digitalisation than mere ICT stock would do. The level of investment relative to total investment tells us how much companies prioritise digitalisation over other places for investment. Also, the level of investment relative to gross value added is presented in some descriptive statistics, although that tells us less about the prioritisation of the management of that industry. For example, construction generates a substantial slice of the economy's value added but it is not an investing industry per se. In construction, the materials and semi-products flow through and are rearranged into structures which we call the built environment. The construction industry's investment in general relative to GVA is modest, which follows the nature of the industry. 
Table 2. Definitions of applied economic variables.

\begin{tabular}{|l|l|l|}
\hline Variable & Definition (Eurostat) & Notes \\
\hline $\begin{array}{l}\text { Gross value } \\
\text { added (GVA) }\end{array}$ & $\begin{array}{l}\text { The value of output at basic prices minus the } \\
\text { value of intermediate consumption at } \\
\text { purchasers' prices. }\end{array}$ & $\begin{array}{l}\text { In essence, GVA describes the value generated by an industry, less the } \\
\text { expenses on services, materials and intermediate products; with value added, } \\
\text { an industry is able to cover wages, profits, interests and leases, for example; } \\
\text { GVA excludes the consumption of fixed capital, i.e. depreciation and } \\
\text { deterioration of assets. }\end{array}$ \\
\hline $\begin{array}{l}\text { Gross fixed } \\
\text { capital stock } \\
\text { formation (GFCF) }\end{array}$ & $\begin{array}{l}\text { Expenditure on new fixed assets plus net } \\
\text { expenditure on second-hand fixed assets, } \\
\text { including both additions and/or replacements. }\end{array}$ & $\begin{array}{l}\text { Expenditure on repair and maintenance of fixed assets is excluded, as is } \\
\text { depreciation of the assets; GFCF is applied as a proxy for total gross } \\
\text { investment made by industries; the change in GFCF is the gross investment. }\end{array}$ \\
\hline $\begin{array}{l}\text { Labour } \\
\text { productivity (LP) }\end{array}$ & $\begin{array}{l}\text { LP estimates are indexes of real GDP (gross } \\
\text { domestic production) or GVA per person } \\
\text { employed or per hour worked. }\end{array}$ & $\begin{array}{l}\text { LP indexes not only reflect the contribution of labour to changes in product } \\
\text { per labour unit but are also influenced by the contribution of capital and other } \\
\text { factors affecting production. }\end{array}$ \\
\hline $\begin{array}{l}\text { Multifactor } \\
\text { productivity } \\
\text { (MFP) }\end{array}$ & $\begin{array}{l}\text { MFP measures the efficiency with which both } \\
\text { labour and capital input deliver output; the } \\
\text { standard weighing is 0.7 for labour } \\
\text { productivity and 0.3 for capital productivity. }\end{array}$ & $\begin{array}{l}\text { MFP as a long-range indicator shows improvements in ways of doing things, } \\
\text { for example technical progress due to digitalisation and automation; the } \\
\text { annual changes of MFP indexes work as a proxy for total productivity } \\
\text { development. }\end{array}$ \\
\hline
\end{tabular}

The comparative analysis is carried out using Spearman's rank correlation, by comparing each industry's ranking with regard to investment in digitalisation and productivity. Investment in digitalisation is measured in a relative sense, i.e. what the share of investment in ICT is compared to the total investment of each industry. The foremost question is the comparison between the two countries when the industries are ranked according to their investment activity in digitalisation and comparing whether the rank patterns are similar. Implicitly, similar patterns would indicate that industries in different countries are moving forward at the same pace, and industry is a better explanation factor for digitalisation than the country where the industry is situated. It is intuitively appealing to think that in today's globalised economy, industries are more or less similar, regardless of the country.

Spearman correlation analysis works well for small samples and in cases where it is only necessary to determine whether the correlation is monotonous (i.e. regardless of the shape of the function, it is either declining or increasing; Marascuilo and Serlin, 1988). As a non-parametric method, it also excuses the shape of the variable distributions. Particularly in comparing different industries that are inherently different in many respects, parametric comparisons are deemed methodologically more complex and less informative than the rank correlation method. The correlation coefficient for Spearman was calculated as follows:

$$
\rho=1-6 \Sigma d i^{2} /\left[n\left(n^{2}-1\right)\right]
$$

where $\rho$ is the correlation coefficient, $d i$ is the difference between the two ranks and $i$ runs from 1 to $n, n$ being the number of cases compared. In this case, $n$ is the number of industries (9). The significance of the coefficient can be tested with Student's t-distribution, where the test variable $t$ is defined as:

$$
t=\rho\left[(n-2) /\left(1-\rho^{2}\right)\right]^{1 / 2}
$$

Critical values for $t$ can be found in almost any statistical textbook or reliable online table (see e.g. http://www.itl.nist.gov/div898/handbook/eda/section3/eda3672.htm). However, for smaller samples, the use of the t-test is not recommended; the correct way is to just evaluate the correlation coefficient itself (see Marascuilo and Serlin, 1988). The critical correlation coefficient values were obtained from Weathington et al. (2012, Appendix B). The choice of this method was because of its simplicity and straightforwardness: we focus on long-range single digits instead of time series analyses and on comparing the industries' digitalisation of the two case countries.

A word of caution when using national accounts data: although it might be regarded as the only reliable source of data for this type of analysis, it might not be perfectly accurate, for a number of reasons. Sampling and surveying are some of the core methods for acquiring the data, which brings one source of possible error. There are also other complex methodological issues influencing the data reliability, validity and accuracy (York and Atkinson, 1997; Zheng, 2005). Despite these possible sources of error, there is factually no alternative data available for research of this kind. 


\section{OBSERVATIONS AND EVIDENCE}

\section{FINLAND}

According to the Federation of Finnish Technology Industries, ICT and digitalisation has been the most noteworthy single factor generating economic growth during the last 15 years in Finland, with about twothirds of growth in the recent decade being due to ICT and digitalisation. Approximately $50 \%$ of work productivity and $40 \%$ of total productivity growth has been attributed to digitalisation (Pohjola, 2014). Also, there is an a priori assumption of correlation between investment in ICT and productivity, applying to both work and total productivities (Straus and Samkharadze, 2011). Correlations are, however, weak, even when large samples are used. This implies that factors other than digitalisation might be playing a stronger role in productivity, such as market conditions and industrial relations, for example (Leviäkangas et al., 2017).

Figure 1 presents the annual arithmetic average of total (MFP) productivity growth in Finland for 20002013 measured by changes in gross value added. The $\mathrm{x}$-axis shows the ranking of 19 industries according to their investment in ICT for 1998-2012. There appears to be a weak relationship between digitalisation (ICT intensity) and productivity, but this relationship is barely visible from the slope of the trend line (which by no means entitles correlation analytics). ICT and digitalisation are not the only determining factors of productivity, even if they did contribute to productivity growth.

The message from the figures is that despite digitalisation, productivity has not been increasing as expected. Also, when comparing industries, there is a weaker correlation between digitalisation and productivity than is generally assumed. Another debate would be whether there is true causality between ICT investment and productivity growth, as well as the fact that we are not able to assess what the productivities of the industries would have been if there were less investment in digitalisation than observed from the national accounts. What is certain from Figure 1 is that investment in digitalisation does not per se ensure productivity, although nor does a lack of investment mean that the industry's productivity is necessarily weak compared to 'digitalisers'.

The 'productive digitalisers' belong to the upper left corner of Figure 1. Information media and telecommunication $(\mathrm{J})$ and retail trade $(\mathrm{G})$ industries belong to this category of productive digitalisers. These industries have invested substantially in ICT and are able to show better long-term total productivity growth. However, agriculture (A), while a 'productive laggard' - or perhaps rather an 'indifferent' industry - has the highest long-term total productivity development of all the industries. Yet investment in digitalisation is one of the most modest. In the lower left corner, financial and insurance services $(\mathrm{K})$ and professional, scientific and technical services (M) have been active investors in digitalisation, but have not been able to transform that investment for some reason into productivity growth. These reasons may well originate from the market and other external factors, such as the financial crisis that started in 2008. The majority of the industries belong to either the group 'unproductive laggards' - those that did not invest and showed poor productivity - or the group 'try hards', i.e. those who obviously invested but were not really able to convert investment into productivity growth. 'The Belt of Low Productivity' follows almost exactly the zero line. It also visualises that the majority of the industries struggle with productivity regardless of their investment in digitalisation. It goes without saying that also in this category market (non-ICT related) other external factors may be the reason for poor total productivity growth. When using Spearman rank correlation calculus, the rank correlation coefficient $\rho=0.135$ falls under the critical significance threshold (Weathington et al., 2012, Appendix B). 

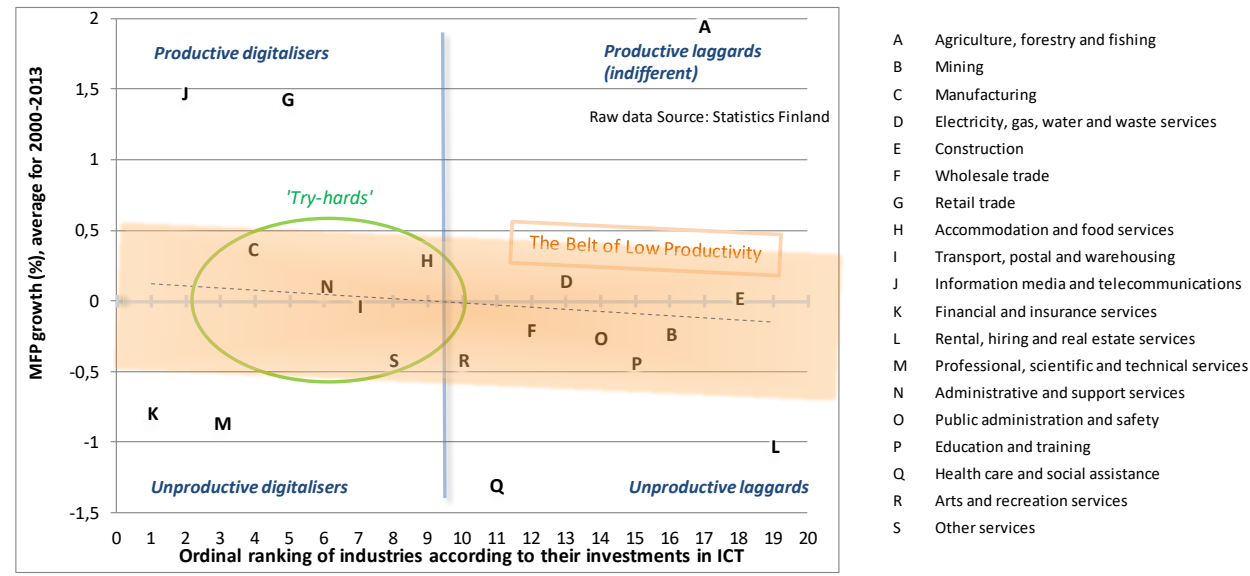

Figure 1. Total (MFP) productivity growth and investment in digitalisation by industry in Finland.

The labour productivity ranking and productivity trends paint a similar picture as did the analysis on total productivity. There seems to be a weak rank correlation between industries' investment in digitalisation and labour productivity, but with the 19 industries full sample, the rank correlation coefficient $\rho=0.026$ is below the critical values of significance (Weathington et al., 2012, Appendix B). This is shown in Figure 2. Information media and telecommunications (J) and retail trade $(\mathrm{G})$ are 'successful digitalisers'. Manufacturing (C) also shows long-term productivity growth with its high level of digitalisation investment. In other words, manufacturing has been able to either reduce the workforce or otherwise increase the work inputs while investing in ICT. However, these seem not to be reflected in total productivity.
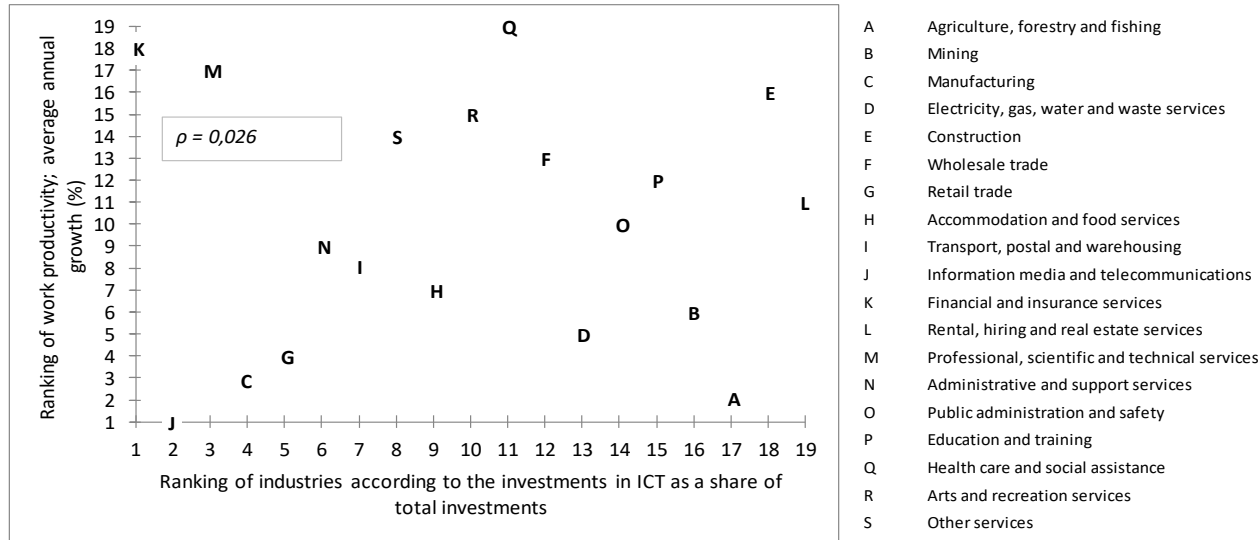

Figure 2. Labour productivity growth and ranking of industries with regard to their investment in digitalisation for 1998-2012 in Finland.

\section{AUSTRALIA}

Australia can be called a country of mining and natural resources (oil and gas) for a good reason. Sectors closely linked to these industries are construction and finance. The former is needed to build the infrastructures for the natural-resource industries and the latter follows mining and natural-resource industries because they are heavily capital intensive and must partly rely on market-based financing. Digitalisation investment has been made particularly in banking, financing and insurance. Almost half of all 
the investment in recent years made by this industry is in ICT. Not surprisingly, information, media and telecom industries are also active investors in ICT. Professional, scientific and technical services are equally active 'digitalisers', too. The time series for selected industries is shown in Figure 3. Investment made in digitalisation relative to the GVA of the industry can be a misleading indicator. Some industries invest less (e.g. construction) in fixed assets and some more (e.g. some utilities of water or electricity) by nature. In the former case, digitalisation investment, as well as the other investment, is modest relative to GVA. In the latter case, a heavy asset base may have no association with low GVA and digitalisation investment may appear overrepresented in the big picture.

It is paradoxical that with the most important industries, long-term productivity development has been negative in Australia. It could be the case that these industries experienced such aggressive (and very positive) growth that productivity was not the number-one priority of industry leaders. This interpretation is partly supported when looking at the GVA growth of Australian industries for 1995-2015. Mining (B), finance and insurance services $(\mathrm{K})$ as well as construction $(\mathrm{E})$ boomed. The first mentioned had poor productivity development for the period of analysis, whereas the other two were moderately well-developed in comparison with the other industries. Also for gas, electricity, water and waste services, productivity seems to have developed negatively. This industry mainly comprises utilities and public or semi-public companies providing basic infrastructure and services for their communities, which may somewhat explain the productivity lag. In essence, the Australian data shows a clear keenness for digitalisation, but similarly with Finland, to translate digitalisation into productivity, especially total productivity, seems to be somewhat of a challenge.

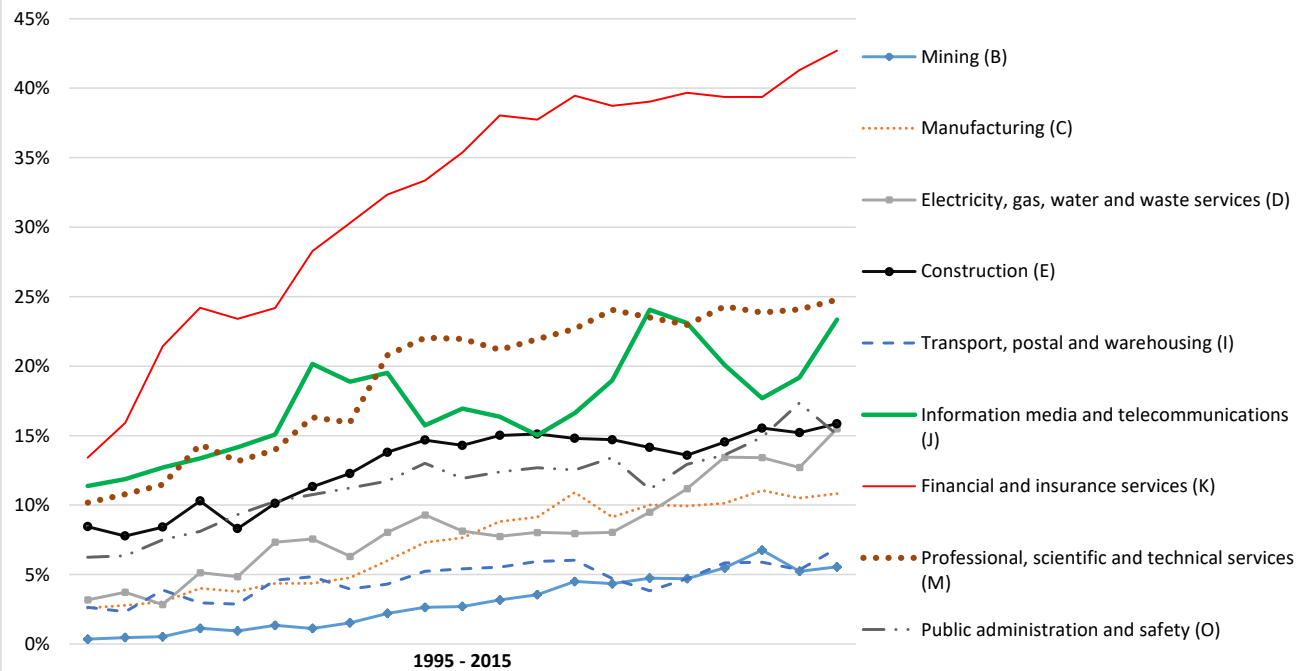

Figure 3. ICT investment as a share of total investment for different Australian industries for 1995-2015. 


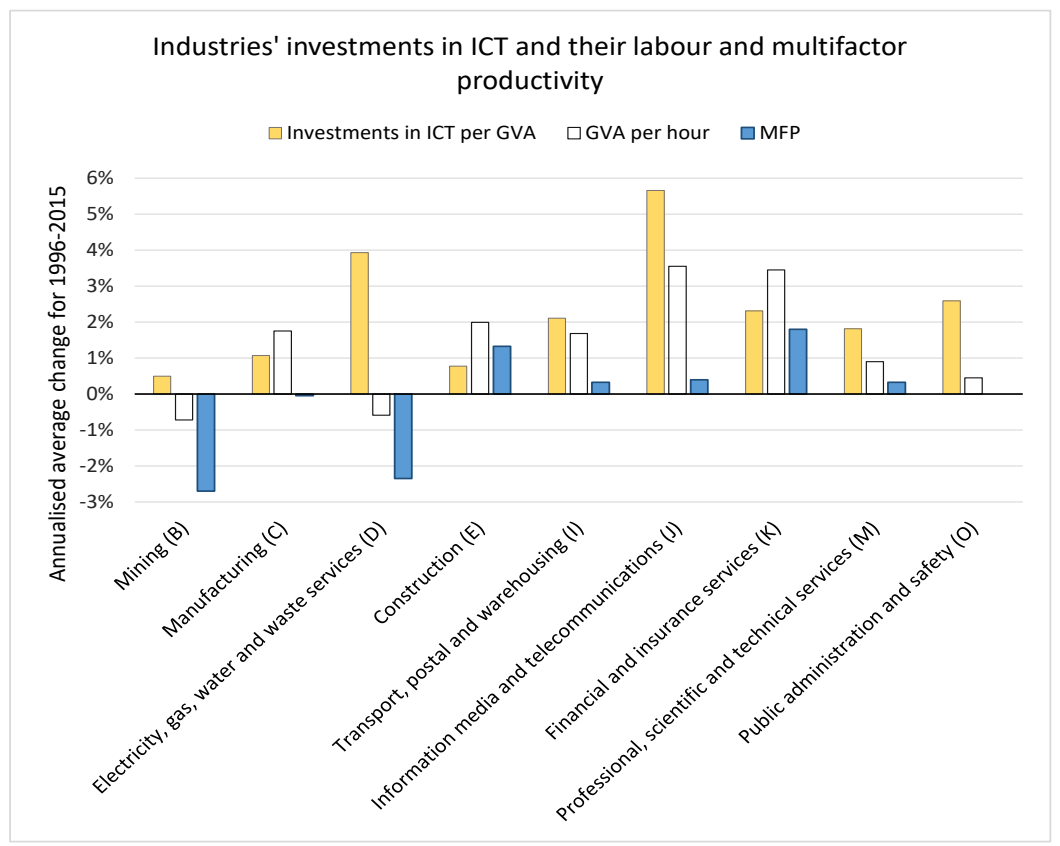

Figure 4. Investment in digitalisation as a share of industries' gross value added and development of work and multifactor productivity in Australia.
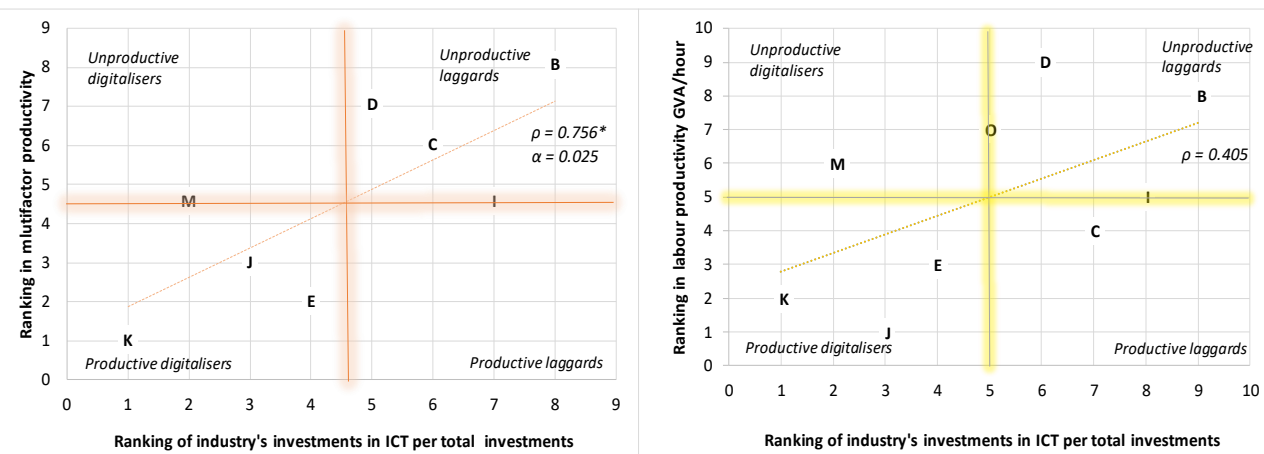

B=Mining,; C=Manufacturing; D=Electricity, Gas, Water and Waste Services; E=Construction; I=Transport, Postal and Warehousing;

$J=$ Information, Media and Telecommunications; $K=$ Financial and Insurance Senvices; M=Professional, Scientific and Technical Services

Figure 5. Rank correlations of selected Australian industries according to their ICT investment per total investment; for Public administration and safety $(\mathrm{O})$ the multifactor data was not available; trend lines only for visualisation purposes.

Although there is no clear pattern of higher digitalisation leading to higher productivity, there is a sign in Figure 5. As depicted in the upper panel of Figure 5, the positive correlation coefficient between an industry's ranking of digitalisation investment and total productivity exceeds critical value 0.738 at risk level 0.025 (rejecting the null hypothesis of $\rho \leq 0$, one-sided test, degrees of freedom $8-2=6$ ). However, when actual percentage units are used and plots drawn, the picture becomes more unclear. A weaker case for the correlation results when labour productivity rankings and digitalisation rankings are plotted, and there is no evident statistical correlation (critical value for rank correlation coefficient $\rho$, for risk level $\alpha=0.1, d f=9$ 
- $2=7$, would be 0.483 , which is not reached). The trend lines are purely for visualisation purposes: Spearman's correlation coefficient indicates a monotonous relationship but not any particular curve shape.

\section{INDUSTRIES’ PACING IN DIGITALISATION}

Both Finland and Australia have a strong digitalisation agenda. This is clear from both governments' plans and programs (Commonwealth of Australia, 2015; Prime Minister's Office Finland, 2015). In order to understand why some industries and sectors are laggards, more in-depth analysis of such cases is needed. We know that industries differ in the level of their digitalisation and we also know that so do the countries. Information on industry differences between the countries is hard to find. Table 3 presents the comparative data for the two countries. It is interesting to observe the somewhat similar patterns in the digitalisation of industries. The first three industries most active in digitalisation are the financial and insurance services (K), information media and telecommunications (J), and professional, scientific and technical services (M). It is noteworthy that the leading troika comprises services industries.

Table 3. Comparative data for Australia and Finland.

\begin{tabular}{|c|c|c|c|c|}
\hline \multirow[t]{2}{*}{ Code } & \multirow[t]{2}{*}{ Industry } & \multicolumn{2}{|c|}{$\begin{array}{l}\text { Ranking of industry in digitalisation } \\
\text { (investment in ICT per total investment) }\end{array}$} & \multirow{2}{*}{$\begin{array}{c}\text { Correlation (rank) between industries' } \\
\text { investment in ICT and productivity } \\
\text { growth }\end{array}$} \\
\hline & & FI & AUS & \\
\hline$B$ & Mining & 8 & 9 & \multirow{9}{*}{$\begin{array}{c}\text { Finland: } \\
\text { Labour productivity: NO } \\
\text { Multifactor productivity: NO } \\
\text { (no. of industries = 19; time series data from } \\
\text { national accounts 1998-2012) }\end{array}$} \\
\hline C & Manufacturing & 4 & 7 & \\
\hline D & $\begin{array}{l}\text { Electricity, gas, water and } \\
\text { waste services }\end{array}$ & 6 & 6 & \\
\hline$E$ & Construction & 9 & 4 & \\
\hline I & $\begin{array}{lll}\begin{array}{l}\text { Transport, } \\
\text { warehousing }\end{array} & \text { postal } & \text { and } \\
\end{array}$ & 5 & 8 & \\
\hline$J$ & $\begin{array}{l}\text { Information media and } \\
\text { telecommunications }\end{array}$ & 2 & 3 & \\
\hline K & $\begin{array}{l}\text { Financial and insurance } \\
\text { services }\end{array}$ & 1 & 1 & \\
\hline M & $\begin{array}{l}\text { Professional, scientific and } \\
\text { technical services }\end{array}$ & 3 & 2 & \\
\hline $\mathrm{O}$ & $\begin{array}{l}\text { Public administration and } \\
\text { safety }\end{array}$ & 7 & 5 & \\
\hline
\end{tabular}

The conclusion is ultimately the following: it is relatively certain that industries found in the two countries follow a somewhat similar pace in digitalisation when comparing industries between themselves. The Spearman rank correlation coefficient $\rho$ is 0.583 , which is not too impressive, but if we test that coefficient against the null hypothesis 'the correlation coefficient $\rho \leq 0$ ', the null hypothesis is rejected at a $90 \%$ confidence level $(\alpha=1)$. However, and as can be witnessed from the plot and table, there are also differences between the countries' industries. But the big picture seems clear enough and is also supported by other previous studies. For industries less advanced in digitalisation, it would likely be worthwhile to monitor the moves and progress of the leading industries.

The most notable difference in digitalisation rankings is with construction (E). One of the possible reasons for this is that construction is one of the main industries in Australia and, in fact, makes one of the highest contributions to the aggregate gross value added of the Australian economy. This obviously gives some manoeuvring space for making investment in digitalisation. When Australia is compared to other countries, it shows that, for example, building information modelling (BIM) is at a fairly high level (Leviäkangas et al., 2017) in construction. A high level of BIM users is also reflected in the digitalisation of professional, scientific and technical services (M); construction designers and architects belong to this industry category. 


\section{SUMMING-UP, IMPLICATIONS AND DISCUSSION}

This article investigated and compared the digitalisation of industries in Finland and Australia. First, the national account data was compiled from 19 industries (full set) from Finland for 1998-2012, and for Australia, 8 industries for 1995-2015. The indicators from the national accounts included annual changes in gross value added, annual changes in gross fixed capital formation (both all items and ICT) and annual changes in work and multifactor productivities, measured by indices. This data formed the observation set. A correlation analysis was conducted between investment in ICT and productivity indicators. It was found that the correlation between industry investment in ICT and productivity growth was weak when making comparisons between industries. The only statistical evidence was found from Australia, implying that industries that on average invested more in ICT for 1995-2015 had better long-term average multifactor productivity development. Statistical evidence, although not very strong due to the limited sample, was found regarding the long-term progress of different industries' digitalisation when comparing the industries of the two countries. This evidence is supported by other evidence, but such evidence is rather scarce.

The implications of the observations and evidence are many. First, it seems that we must be careful not to overestimate the potential productivity leaps that digitalisation is supposed to deliver. Productivity may well be there as a result of investing in ICT, but ICT is not the only decisive factor. Other factors, such as input prices, market success, government regulations, etc. might have a more substantial impact. Often managers of companies are blamed for not accounting properly for technological progress placing too little emphasis on introducing new technology to the value-adding processes of their companies. That claim should not be presented too strongly in the light of the aforementioned evidence. Managers just might be realistic in their priorities.

As pointed out by Andrews et al. (2016), it may also be that there is a divergence process: the leaders (successful digitalisers) are increasing their lead and there is less, or at least slower, technology diffusion taking place between companies and across the industries, leaving the laggards further behind. Another explanation that Andrews et al. (2016) give is that perhaps the markets are not that efficient and competitive, in the end. This would result in slower and less creative destruction that would happen in efficient and highly competitive markets. This dualism was identifiable from the small sample of Australian firms, as most companies fell either into the category of 'productive digitalisers' - and hence successful - whereas the other main group belonged to 'unproductive laggards'. It seems that not only are there firms who 'get it', there are also industries that are 'getting it' while others are 'not getting it'. The studied sample was small, but, on the other hand, the time period covered was extensive.

Second, there seems to be a pattern that some industries are leading the digitalisation, regardless of the country where the industry is situated. This conclusion is, of course, a tentative one and founded only on the two case analyses performed. However, some published reports point in the same direction: for example, similar patterns were reported by Gandhi, Khanna and Ramaswamy (2016), although their analysis was based on expert interviews and some undefined data analysis. More solid evidence is provided based on the Eurostat data, again showing similar patterns when comparing industries (Friedrich et al., 2011). If the conclusion is correct (as it tentatively seems), and we may expect that some universality can be applied here, it is the forerunners of digitalisation we should keep our keen eyes on when we consider what the digital revolution will bring and how likely it is to have an impact on business. The financing and insurance industries in Australia are already investing almost 50\% of all their tangible investment in ICT. This is surely significant and will have not only immediate but also long-term implications.

One of the explaining factors as to why finance and insurance services are in the forefront of digitalisation, is that the 'commodity' these industries handles is already digitalised. According to the American Consumer Credit Card Counselling survey statistics, $80 \%$ of consumers use their debit or credit cards for everyday purchases (e.g. gasoline, meals, groceries). In the 18-24 years age group, the corresponding share is $100 \%$. The same patterns of cash use dying out are seen in Australia (Hutchens, 2015; Reserve Bank of Australia, 2017) and Finland (Bank of Finland, 2016). Advancing digitalisation will obviously further reduce the use of cash. A reflection back to Schumpeter's theory of creative destruction makes us question whether the destruction has now started in the financial and insurance services as well as the other industries leading the digitalisation. Looking at the level of investment, public statements of high-level banking officers and the 
rapid disappearing of the usual 'commodity', it is hard not to come to this conclusion. In Finland, the major banks have openly stated the loss of thousands of jobs in the industry while at the same time recruiting thousands of digitalisation experts. One of the leading bank's CEOs estimated, in a public interview to the Finnish Broadcasting Company (Yleisradio), that as much as $40 \%$ to $50 \%$ of the traditional banking business may disappear in the years to come (https://yle.fi/uutiset/3-9336816). Citigroup's former head recently said that $30 \%$ of traditional bank jobs would be gone within five years (Fortune, 2017). The question is whether the big players are able to weather out and adapt to the disruption. We have also seen other industries, such as retail, entering the banking business.

Digitalisation requires resources; it will not happen without human labour and effort. If the demand for ICT products and services is constantly increasing, one of the concerns is whether there will be enough supply to satisfy the demand. It may well be that the sadly notorious ICT projects, which tend to be delayed and exceed their budgets, are a signal indicating inadequate supply in terms of quantity and quality to meet the demand. The recent concern over the lack of coders and programmers manifests the current and seemingly widening gap between expertise supply and demand (Financial Times, 2016). Supply shortcomings may well be a bottleneck on the way of digitalisation and may also further explain some of the poor productivity numbers we are witnessing despite some heavy investment in digitalisation. The need to renew the education systems to address the demand for digital skills has been flagged by the OECD (2014).

Third, there is a need to study digitalisation with more refined resolution. Research that takes a firm-level view would be very valuable and add to the body of knowledge, and furthermore, add to our comprehension of how ICT and digitalisation can be put to work wisely. Such studies are rare and most likely confidential. This is for reasons that are easy to understand: strategies on how to digitalise business are often talked and written about, but few stories are available that show how this is actually done. The unsuccessful stories sometimes hit the headlines and in very few instances, if ever, get to be thoroughly researched.

Fourth, for countries not yet technologically as advanced as Finland or Australia, the presented analysis forms a benchmark (see e.g. the Nigerian case by Oladipo et al., 2016). Rather than rushing to digitalise and invest hastily in ICT, it would be good to understand which industries are the natural leaders and how to make inter-industry technology transfer. For example, it has long been debated how the construction industry should learn from manufacturing, but little progress has been made, to be honest. In countries where industries are still in the rapid development phase, it is tempting to think that digitalisation might have a more fertile ground. There are fewer lock-ins, both cultural and technological, in countries with a shorter high-tech history; also, there might be lower organisational and administrational barriers to do things in a novel manner. Last but not least, there is potentially a more open mind-set towards innovative application of digital technologies. In these situations, and at the gate of new prospects, developing economies must have the courage to do things in their own way and not imitate too much the more advanced nations. A good example of such a self-confident approach can be found neighbouring Finland, namely in Estonia. Estonia has taken sizable leaps in digitalisation and is the first country in the world to have a fully digital citizen identity system, to have digital referenda, as well as building a pioneering e-government (see: https://eestonia.com/the-story/how-we-got-there/).

When organisations digitalise their processes, be these manufacturing or service or both, that will only be half of the story. There are equally strong technological drivers that go hand in hand with digitalisation, such as automation and robotisation. These technology drivers have an interference effect: the more one incorporates automation, the easier it will be to digitalise and vice versa. Digital technologies enable instant measurements and diagnostics, which are needed for automation. Automation, in turn, makes everything easier to measure and diagnose. It seems perfectly logical that these drivers interact and have an interference effect not only on the deployment speed of technology, but also have wider impacts on society. There are new emerging digital technologies that might have additional disruptive effects. One of the recent examples is blockchain technology, which has the potential to change the nature of digital agreements and build up new digital ecosystems (Kinnunen et al., 2017). As digitalisation makes progress at a relentless pace, it will 
likely bring further disruptive effects and confirm some of the perspectives Schumpeter had already before World War I.

\section{STATEMENT}

The data used in this study is openly available from the databases of Statistics Finland, https://www.stat.fi/til/index_en.html, and the Australian Bureau of Statistics http://www.abs.gov.au/.

\section{REFERENCES}

Acemoglu, D., Autor, D., Dorn, D., Hanson, G.H. and Price, B. (2014) 'Return of the Solow paradox? IT, productivity, and employment in US manufacturing', American Economic Review: Papers \& Proceedings 2014, Vol. 104 No. 5, pp.394 - 399. http://dx.doi.org/10.1257/aer.104.5.394.

Andrews, D., Criscuolo C. and Gal P.N. (2016) The Best versus the Rest: The Global Productivity Slowdown, Divergence across Firms and the Role of Public Policy, OECD Productivity Working Papers, 2016-05, OECD Publishing, Paris.

Australian Bureau of Statistics. (2016) 5216.0-Australian system of national accounts: concepts, sources and methods, 2015, 2016. http://www.abs.gov.au/ausstats/abs@.nsf/mf/5216.0 (Accessed 22 March 2016).

Baines, T.S., Lightfoot, H.W., Evans, S., Neely, A., Greenough, R., Peppard, J., Roy, R., Shehab, E., Braganza, A., Tiwari, A., Alcock, J.R., Angus, J.P., Bastl, M., Cousens, A., Irving, P., Johnson, M., Kingston, J., Lockett, H., Martinez, V., Michele, P., Tranfield, D., Walton, I.M. and Wilson, H. (2007) 'State-of-the-art in product-service systems. Proceedings of the Institution of Mechanical Engineers, part B.' Journal of Engineering Manufacture, Vol. 221 No. 10, pp.1543 - 1552.

Bank of Finland. (2016) Käteisen käyttö 2015 ja käteistä kaupan kassalta -palvelu [Use of cash and withdrawals from the counters]. Presentation of Päivi Heikkilä, Bank of Finland. https://www.suomenpankki.fi/globalassets/fi/raha-ja-maksaminen/maksujarjestelmat/suomen-pankkikatalystina-maksuneuvosto/mn06_kateisen_kaytto_2015_ja_kateista_kaupan_kassalta_palvelu.pdf (accessed December 1, 2017).

Berger, T. and Frey, C. (2016) Structural Transformation in the OECD: Digitalisation, Deindustrialisation and the Future of Work, OECD Social, Employment and Migration Working Papers, No. 193, OECD Publishing, Paris, available at: http://dx.doi.org/10.1787/5jlr068802f7-en.

Brea, E., Kambouris, P., Elfes, A., Duff, E., Bick, M., Bonchis, A., Tews, A. and Lopes, L. (2013) An initiative to enhance SME productivity through fit for purpose information and robotic technologies, Commonwealth Scientific and Industrial Research Organisation, 2013. May 2013.

Brynjolfsson, E. and Yang, S. (1996) 'Information technology and productivity: a review of the literature', Advances in Computers, Vol. 43, pp.179 - 214.

Brynjolfsson, E. and Hitt, L.M. (2000) 'Beyond computation: information technology, organizational transformation and business performance', Journal of Economic Perspectives, Vol. 14 No. 4, pp.23 - 48.

Brynjolfsson, E. and McAfee, A. (2014) The Second Machine Age: Work, Progress, and Prosperity in a Time of Brilliant Technologies, WW Norton \& Company, New York.

Colander, D. (1992) 'Retrospectives: the lost art of economics', The Journal of Economic Perspectives, Vol. 6 No. 3, pp.191 - 198.

Commonwealth of Australia. National Innovation and Science Agenda, Department of the Prime Minister and Cabinet (2015). 
Drejer, I. (2004) 'Identifying innovation in surveys of services: a Schumpeterian perspective', Research Policy, Vol. 33 pp.551 - 562.

European Commission. (2015a) Digitising European industry - background paper. Background paper for the round-table of leaders of European initiatives on "Digitising European Industry" European Commission, DG Connect, Components and Systems.

European Commission. (2015b) Digital agenda targets progress report. Digital agenda scoreboard.

Financial Times. (2016) 'Curriculum experts say coding is essential in a digital economy', Financial Times, May 4, 2016.

Fortune. (2017) 'The former head of Citigroup says $30 \%$ of bank jobs will be gone in five years', Fortune, http://fortune.com/2017/09/13/the-former-head-of-citigroup-says-30-of-bank-jobs-will-be-gone-in-fiveyears/ (accessed October 3, 2017).

Friedrich, R., Le Merle, M., Grone, F. and Koster, A. (2011) Measuring Industry Digitization - Leaders and Laggards in the Digital Economy, Booz \& Company, New York.

Gandhi, P., Khanna, S., and Ramaswamy, S. (2016) 'Which industries are the most digital (and why)?' Harvard Business Review [online] https://hbr.org/2016/04/a-chart-that-shows-which-industries-are-themost-digital-and-why. (Accessed 3 October 2017).

Holt, L. and Jamison, M. (2009). 'Broadband and contributions to economic growth: lessons from the US experience', Telecommunications Policy, vol. 33 No. 10-11, pp.575 - 581.

Hutchens, G. (2015) ‘Australians are using less cash and more card to pay and play every day', The Sydney Morning Herald, January 24, 2015.

Jovanovic, B. and MacDonald, G. (1994) 'Competitive Diffusion', Journal of Political Economy, Vol. 102 No. 1, pp. 24 - 52.

Kinnunen, T., Leviäkangas, P., Kostiainen, J., Nykänen, L., Rouhiainen, K. and Finlow-Bates, K. (2017) Lohkoketjuteknologian soveltaminen ja vaikutukset liikenteessä ja viestinnässä [Application of blockchain technologies in transport and communications sector], Publications of the Ministry of Transport and Communications Finland 12/2017 (Finnish only, English abstract).

Leonardi, P.M. and Barley, S.R. (2008) 'Materiality and change: challenges to building better theory about technology and organizing', Information and Organization, Vol. 18 no. 3, pp.159 - 176.

Leviakangas, P. (2016) 'Digitalization of Finland's transport system', Technology in Society, Vol. 47 pp.1 15. http://dx.doi.org/10.1016/j.techsoc.2016.07.001.

Leviäkangas, P., Mok Paik, S., and Moon, S. (2017) 'Keeping up with the pace of digitization? The case of the Australian construction industry', Technology in Society, Vol. 50 pp.33 - 43.

Marascuilo, L.A. and Serlin, R.C. (1988) Statistical Methods for the Social and Behavioral Sciences, W.H. Freeman and Company, New York, 1988.

OECD. (2009) Measuring capital. OECD Manual, $2^{\text {nd }}$ ed. 
OECD. (2012) Income distribution data review, OECD, United States, 2012. http://www.oecd.org/els/soc/OECDIncomeDistributionDataReview-UnitedStates.pdf (Accessed 12 November 2015).

OECD. (2014) 'Skills and Jobs in the Internet Economy', OECD Digital Economy Papers No. 242, Paris, France.

OECD. (2015) The Future of Productivity - Preliminary Version, OECD Publishing.

Oladipo, O., Murphy, A., Anannsingh-Jamieson, F. and Amaghionyeodiwe, L. (2016) 'Information and communication technology, and economic growth in Nigeria: a time series analysis', International. Journal of Technology, Policy and Management, Vol. 16 No. 2, pp.149 - 162, DOI: 10.1504/IJTPM.2016.076315.

Perrow, C. (1967) 'A framework for the comparative analysis of organizations', American Sociological Review, Vol. 32 No. 2 (April 1967), pp.194 - 208.

Pohjola, M. (2014) Suomi Uuteen Nousuun. ICT ja digitalisaatio tuottavuuden ja talouskasvun lähteinä, The Finnish Federation of Technology Industries, 2014. (In Finnish only).

Prause, J. (2016) ‘Digitization vs. Digitalization - Wordplay or World View?’ SAP News, May 11, 2016.

Prime Minister's Office. (2015) Finland, a land of solutions, strategic programme of Prime Minister Juha Sipila's government.

Reserve Bank of Australia. (2017) 'How Australians Pay: New Survey Evidence', Reserve Bank of Australia Bulletin, March, 2017.

Rogers, E.M. (1983) Diffusion of Innovations, $3^{\text {rd }}$ ed., New York: The Free Press.

Schumpeter, J.A. (1934) 'The theory of economic development: an inquiry into profits, capital, credit, interest, and the business cycle', Harvard Economic Studies Vol. 46.

Shin, N. and Chen, Q. (2016) 'An exploratory study of nonprofit organisations' use of the internet for communications and fundraising', International. Journal of Technology, Policy and Management, Vol. 16 No. 1, pp.32 - 44, DOI: 10.1504/IJTPM.2016.075937.

Shinozaki, A. (2008) 'Japan's IT puzzle: neither a Solow paradox nor a new economy', InfoCom REVIEW, Vol. 44, pp.22 - 31.

Solow, R.M. (1987) ‘We’d better watch out’, New York Times Book Review, July 12, 1987.

Stiroh, K.J. (2005) 'Reassessing the impact of IT in the production function: a meta-analysis and sensitivity tests', Annales D'Économie et de Statistique Vol. 79/80, pp.529 - 561.

Strauss, H. and Samkharadze, B. (2011) 'ICT capital and productivity growth, No. 2', in Strauss, H. (Ed.), EIB Papers, vol. 16 European Investment Bank, Luxembourg pp.20.

Sweezy, P.M. (1943) 'Professor Schumpeter's theory of innovation', The Review of Economics and Statistics, Vol. 25 No. 1, pp.93- 96.

Triplett, J.E. (1999) 'The Solow productivity paradox: what do computers do to productivity?' The Canadian Journal of Economics / Revue canadienne d'Economique, Vol. 32 No.2, pp.309 - 334. 
United Nations, European Commission, International Monetary Fund, Organisation for Economic Cooperation and Development OECD, World Bank. (2009) System of National Accounts 2008, 2009. New York.

Weathington, B.L., Cunningham, C.J.L. and Pittenger, D.J. (2012) Understanding Business Research, $1^{\text {st }}$ ed. John Wiley \& Sons, Inc.

Wonglimpiyarat, J. (2018) 'The role of government in Porter's diamond model: comparative cases of Singapore and Thailand', International Journal of Technology, Policy, and Management, Vol. 18 No.1, pp.73 - 88, DOI: 10.1504/IJTPM.2018.10008887.

World Economic Forum. (2015a) Deep Shift, Technology Tipping Points and Societal Impact, Global Agenda Council on the Future of Software \& Society, Geneva, Switzerland.

World Economic Forum. (2015b) The Global Competitiveness Report 2015-2016, (Insight Report. Geneva, Switzerland).

Yin, R.K. (2014) Case Study Research: Design and Methods, Sage, Los Angeles, CA.

York, R. and Atkinson, P. (1997) The Reliability of Quarterly National Accounts in Seven Major Countries: a User's Perspective, OECD Economics Department, Working Papers, No. 171, OECD Publishing, http://dx.doi.org/10.1787/184371668631.

Zheng, S. (2005) 'Estimating industry-level multifactor productivity for the market sector industries in Australia: methods and experimental results, research paper', Australian Bureau of Statistics, July 14, 2005.

Ziemnowicz, C. (2013) 'Joseph A. Schumpeter and innovation', in Carayannis, E.G. (Ed.), Encyclopedia of Creativity, Invention, Innovation, and Entrepreneurship, [online] http://dx.doi.org/10.1007/978-1-46143858-8 (accessed October 3, 2017). 